\title{
Establishment and maintenance of pregnancy after embryo transfer in ovariectomized mares treated with progesterone
}

\author{
K. Hinrichs, P. L. Sertich, E. Palmer* and R. M. Kenney
}

Section of Reproductive Studies, New Bolton Center, School of Veterinary Medicine, University of Pennsylvania, Kennett Square, PA 19348, U.S.A. and*Institut National de Recherche Agronomique, Station de Physiologie de la Reproduction, Centre de Recherches de Tours, Nouzilly 37380, France

\begin{abstract}
Summary. Pregnancy was established and maintained after embryo transfer in 3 ovariectomized mares treated with progesterone only. Four ovariectomized mares were used as recipients, and 7 transfers were performed. Progesterone in oil, $300 \mathrm{mg}$ i.m. daily, was given starting 5 days before transfer of a 7-day embryo. If the mare was pregnant at 20 days, progesterone treatment was continued to 100 days of gestation. The 3 pregnant mares carried to term and delivered live foals with normal parturition, lactation and maternal behaviour. No differences were seen between pregnant and non-pregnant ovariectomized mares in jugular plasma concentrations of oestrogen, LH or FSH from day of transfer (Day 7) to Day 20. Pregnant ovariectomized mares showed a rise in LH, reflecting production of horse CG, starting at Day 36. Oestrogen values remained low until Day 50.
\end{abstract}

\section{Introduction}

Ovarian steroid requirements for the establishment and maintenance of pregnancy have been investigated in many species. Much of this work has been done using mated females ovariectomized after ovulation and given exogenous hormones to maintain pregnancy (reviews, Sauer, 1979; Levasseur, 1984). In these studies, the uterus has been influenced by endogenous hormones before and during the oestrus immediately preceding pregnancy.

The ovarian hormone requirements for pregnancy in long-term ovariectomized females (i.e. ovariectomized before the oestrus and ovulation associated with pregnancy) may be studied using embryo transfer and hormone replacement therapy. These requirements have been determined for some species, notably the rat (Psychoyos, 1961), mouse (Humphrey, 1969) and ewe (Miller \& Moore, 1976).

In the mare, ovariectomy before 50 days of gestation results in abortion. Between 50 and 70 days, progestagen production from the placenta may be adequate to maintain pregnancy if the ovaries are removed (Holtan et al., 1979). Administration of progestagens can maintain pregnancy in mares ovariectomized at 25-35 days of gestation (Terqui \& Palmer, 1979; Shideler et al., 1982), and in mares after lysis of the corpus luteum by prostaglandin treatment at 10 days of gestation (Parry \& Holtan, 1985). In a study involving transfer of horse embryos into mules (sterile donkeyhorse hybrids), pregnancy was established in one mule that had no apparent ovarian activity (Davies et al., 1985). This mule was treated with a synthetic progestagen (allyltrenbolone) starting 5 days before transfer, and pregnancy was maintained using this treatment until abortion occurred between 50 and 60 days of gestation.

The horse conceptus produces oestrogens in vitro as early as 8 days of gestation (Flood et al., 1979; Zavy et al., 1979; Heap et al., 1982). The conceptus is highly motile in the uterus up to 15 days (Ginther, 1983) and contact between it and a large portion of the endometrium is important in pregnancy recognition (McDowell et al., 1985). Maternal recognition of pregnancy occurs in the 
mare at about 15 days of gestation (Hershman \& Douglas, 1979). The mechanism by which the presence of the embryo leads to prolongation of luteal function in horses is not known, but probably involves inhibition of prostaglandin synthesis or release from the uterus (Sharp et al., 1984).

The purpose of this study was to determine whether progesterone alone can prepare the longterm ovariectomized mare for the establishment and maintenance of pregnancy after embryo transfer. After the establishment of pregnancy in ovariectomized mares, oestrogen concentrations were measured to determine whether a rise in peripheral oestrogen due to embryonic production could be detected at the time of maternal recognition of pregnancy. Similarly, FSH and LH concentrations were studied to determine patterns in early pregnancy in the absence of ovarian hormone influence.

\section{Materials and Methods}

Ovariectomized recipients. Four light horse mares, about $5-8$ years of age and $400-500 \mathrm{~kg}$, with normal reproductive tracts at palpation per rectum and Category I or I-II endometria by biopsy (Kenney, 1978) were ovariectomized 10 months before the start of this study. The mares were subsequently given oestrogen or progesterone as part of another project. No treatments were given for at least 18 days before the start of the present study.

Embryo donors. Sixteen mares from 5 to 17 years of age and with varied reproductive histories were used as embryo donors. The mares were teased with a stallion 3 times weekly to detect oestrus. When mares were in oestrus, the genital tracts were palpated per rectum and examined by ultrasonography daily. Based on follicle size and consistency, mares in oestrus were artificially inseminated every other day with extended semen from a fertile stallion (Kenney et al., 1975). At least $500 \times 10^{6}$ progressively motile spermatozoa were used for insemination. The day of ovulation was determined by ultrasonography (Ginther, 1986). The day of donor ovulation, designated Day 0 , was used as the reference for age of the embryo and day of gestation after transfer.

Embryo collection and transfer. After donor mare ovulation, an ovariectomized mare was selected as recipient. The recipient was given progesterone, $300 \mathrm{mg}$ in sesame oil i.m. daily, starting on Day 2 after donor ovulation. Injected volume was $3 \mathrm{ml}(100 \mathrm{mg} / \mathrm{ml})$, this resulted in minor irritation at the injection sites. Progesterone treatment was started on Day 2 to simulate the recipient ovulating 2 days after donor ovulation, the relationship that appears to produce optimal results in intact recipients (Douglas, 1982; Squires et al., 1982). Initially, the uteri of donor mares were flushed on Day 7 for embryo recovery. However, because of a low embryo recovery rate, after the first month of the experiment donor mares ovulating within 1 day of each other were grouped to be flushed at the same time (Day 7 or 8 depending on the day of ovulation). When donor mares were grouped, the recipient was started on progesterone treatment on Day 2 after the last ovulation. In this way, each recipient received progesterone for 5 days before embryo transfer. Uterine flush of the donor mare and transfer of the recovered embryo to the uterus of the recipient were performed transcervically as described by Douglas (1982), with the modification that the transfer was performed entirely per vaginam, without grasping the uterus per rectum. If no embryo was recovered, progesterone treatment of the recipient mare was discontinued, and the mare remained untreated for a minimum of 4 days before preparation for another transfer.

After successful recovery and transfer, recipient mares were maintained on progesterone, $300 \mathrm{mg}$ in oil i.m. daily. The presence of an embryonic vesicle was determined by palpation per rectum and ultrasonography. If no vesicle was apparent at examination at Day 20, progesterone treatment was discontinued and the mare remained untreated for a minimum of 4 days before preparation for another transfer.

If a vesicle was present, treatment with progesterone was continued. Pregnancy was monitored by palpation per rectum and by ultrasound examination for vesicle size and clarity, presence of an embryo, and fetal heartbeat. Progesterone treatment was discontinued at Day 100.

Heparinized jugular blood samples $(10 \mathrm{ml})$ for hormone assay were taken from recipient mares between 09:00 and 11:00 h daily from Day 2 to Day 20 . Blood was centrifuged for $10 \mathrm{~min}$ and plasma removed and stored at $-20^{\circ} \mathrm{C}$ until analysed. Pregnant recipients were similarly bled daily to Day 50, 3 times weekly to Day 100, and once weekly to Day 130.

Controls. To control for flush and transfer techniques, 6 intact mares aged 3-9 years, with normal reproductive tracts at palpation per rectum and Category I endometria by biopsy, were used as embryo transfer recipients. Two donor mares were used. Ovulation of donor and recipient mares was synchronized using oestrogen, progesterone and prostaglandin as described by Loy et al. (1981). Recipients were used if they ovulated on the same day as or up to 3 days after the donor. Ovulation detection, mating of donor mares, and flushing and transfer procedures were performed as above. Differences in pregnancy rate per embryo transferred between ovariectomized and control recipients were determined using Fisher's exact test.

Hormone assays. Total plasma oestrogens were assayed by the method described by Palmer \& Terqui (1977). Oestrogen conjugates were enzymically hydrolysed before extraction, followed by radioimmunoassay of oestrone 
using an antiserum to oestrone with crossreactivity to other oestrogens (oestratriene-3-ol-17-one, 100\%; oestratriene-

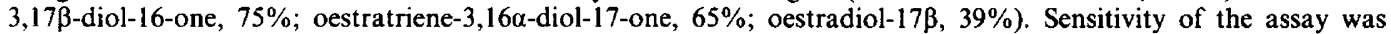
$100 \mathrm{pg} / \mathrm{ml}$. The intra-assay coefficient of variation (CV) was $7 \%$ for a sample of $2 \mathrm{ng} / \mathrm{ml}$ and the inter-assay CV was $17 \%$ for a sample of $3.8 \mathrm{ng} / \mathrm{ml}$.

Plasma progesterone concentration was quantitated as previously described (Ginther et al., 1985), using rabbit antibody raised against progesterone-3-carboxymethyloxime-bovine serum albumin. The sensitivity of the assay was $200 \mathrm{pg} / \mathrm{ml}$. Cross-reactivity for steroids at $50 \%$ displacement was: $5 \alpha$-pregnane-3,20-dione, $18 \%$; pregnenolone, $9 \%$; $11 \alpha$-hydroxyprogesterone, 17a-hydroxyprogesterone, 20a-dihydroprogesterone, aldosterone, oestradiol, oestriol, testosterone, dihydrotestosterone, and androstenedione, $<2 \%$. The intra-assay and inter-assay CVs for pooled plasma from dioestrous mares, run in triplicate, were $8 \cdot 3 \%$ and $9.7 \%$ respectively.

LH was assayed by the modified method of Pelletier et al. (1982), using ${ }^{125}$ I-labelled sheep LH, an anti-sheep LH antibody produced in guinea-pigs and a second horse anti-guinea-pig globulin antibody. The standard curve for mare plasma was calculated using horse LH (Papkoff E98A) and the results are given as ng Papkoff LH (1 Papkoff LH = $3 \times$ NIH-LH-SI in the ovarian ascorbic acid depletion test). For parallelism the same plasma sample was measured in different volumes and then calculated as $\mathrm{ng} / \mathrm{ml}$ plasma. Linearity was correct from 25 to $300 \mu \mathrm{l}$ of plasma. The cross-reactivities of this assay were: horse CG, 100\%; horse FSH (Papkoff E99B and McShan, see Licht et al., 1979), 3 and $18 \%$; hCG, $5 \%$. The sensitivity was $1 \mathrm{ng} / \mathrm{ml}$. The intra- and inter-assay CVs were 13 and $33 \%$ respectively for plasma containing $19 \mathrm{ng} / \mathrm{ml}$, and 14 and $20 \%$ for plasma containing $27 \mathrm{ng} / \mathrm{ml}$.

Plasma FSH concentrations were measured with an homologous horse FSH assay adapted from the method of Blanc \& Poirer (1979) for sheep FSH. The horse hormone (eFSH-A) used as a standard and iodinated as a tracer was that isolated by Combarnous (1980). This purified hormone has an activity equivalent of $169 \times$ FSH-NIH-SI per mg (Combarnous \& Henge, 1981). The first antibody was obtained from rabbit antiserum raised against horse FSH-B (Combarnous \& Henge, 1981). Cross-reactivity of the rabbit antibody with horse LH or horse CG is $<3 \%$. Precipitation was obtained with the addition of sheep anti-rabbit globulin serum. For parallelism 3 plasma samples were measured in different volumes and then calculated as $\mathrm{ng} / \mathrm{ml}$. Linearity was correct from 6.25 to $50 \mu \mathrm{l}$ plasma. The sensitivity of the assay was $6 \mathrm{ng} / \mathrm{ml}$, the intra-assay CVs were 14 and $13 \%$ for plasma containing 10 and $38 \mathrm{ng} \mathrm{FSH} / \mathrm{ml}$ respectively. The inter-assay $\mathrm{CVs}$ were 19 and $23 \%$ for the same plasma samples.

Differences in progesterone, total plasma oestrogens, LH and FSH concentrations from Day 7 (day of transfer) to Day 20 for ovariectomized recipients when pregnant or not pregnant were evaluated by analysis of variance for repeated measures.

\section{Results}

\section{Ovariectomized recipients}

From 25 embryo recovery attempts performed on donor mares, 7 embryos were recovered for transfer into the 4 ovariectomized recipients. Of the 7 transfers, 3 resulted in pregnancy: Mares 1 and 3 maintained pregnancy after the first transfer and Mare 2 after a second transfer. The 3 pregnancies resulted from transfer of 7-day embryos. Mare 4 received embryos on 3 occasions without maintaining pregnancy. After the second and third transfers in this mare, ultrasonography revealed numerous cystic areas in the uterus. The cysts regressed after cessation of progesterone treatment.

Because of the low embryo recovery rate, no recipient received an embryo on the first preparation for transfer. The number of days recipients were untreated before beginning preparation for the transfer that resulted in pregnancy were 10, 27, and 11 days for Mares 1,2 and 3 respectively.

Pregnancies developed normally as determined by ultrasound examination and palpation per rectum. All 3 mares delivered normal foals within 10 days of expected foaling date $(330,343$ and 338 days), with normal parturition, colostrum formation and lactation, and maternal behaviour.

\section{Controls}

Ten embryo recovery attempts were performed in donor mares. Seven embryos were recovered and transferred into the 6 intact recipients, for 5 pregnancies: 4 of the mares maintained pregnancy after the first transfer and 1 mare maintained pregnancy after a second transfer. There was no significant difference in pregnancy rate per embryo transferred between ovariectomized and control recipient mares. 

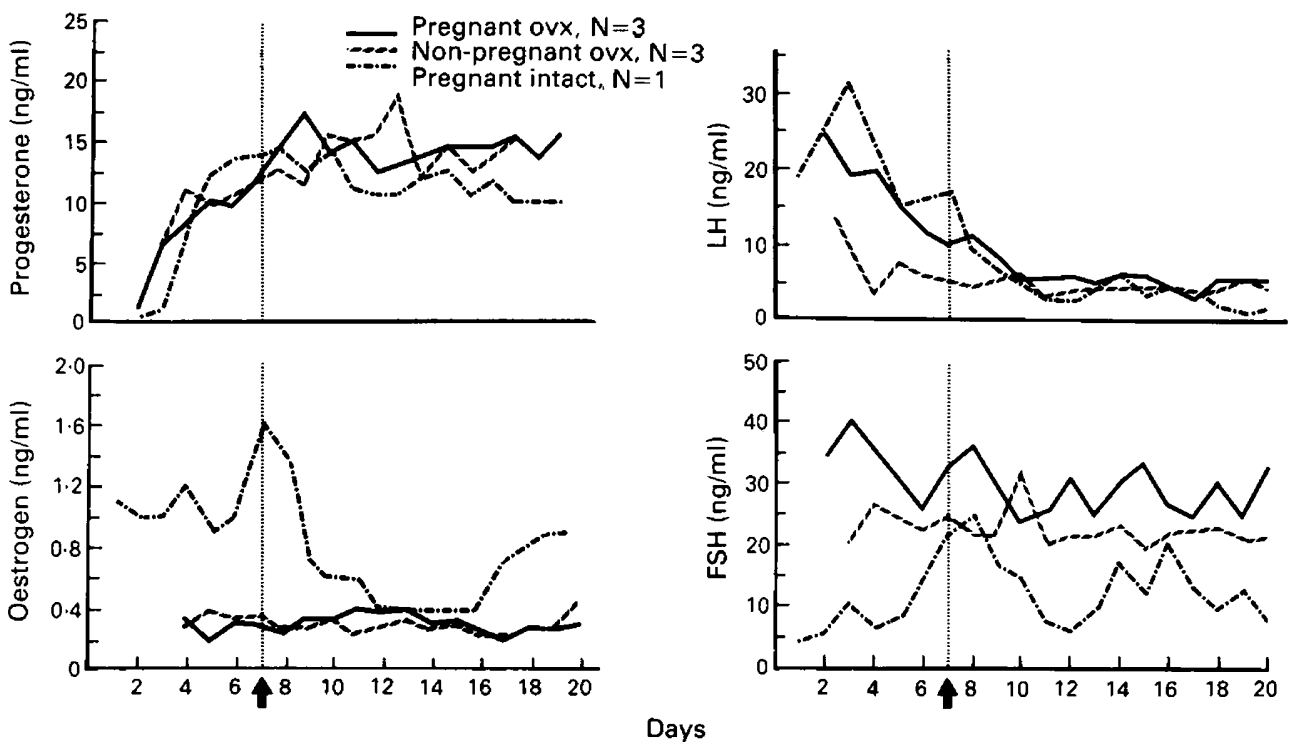

Fig. 1. Hormone concentrations in pregnant and non-pregnant ovariectomized (ovx) recipient mares, and for an intact pregnant recipient mare. Day of embryo transfer $=$ Day 7 (arrow). Values for ovariectomized mares are expressed as means of 3 animals. There were no significant differences in hormone concentrations between pregnant and non-pregnant ovariectomized recipients.
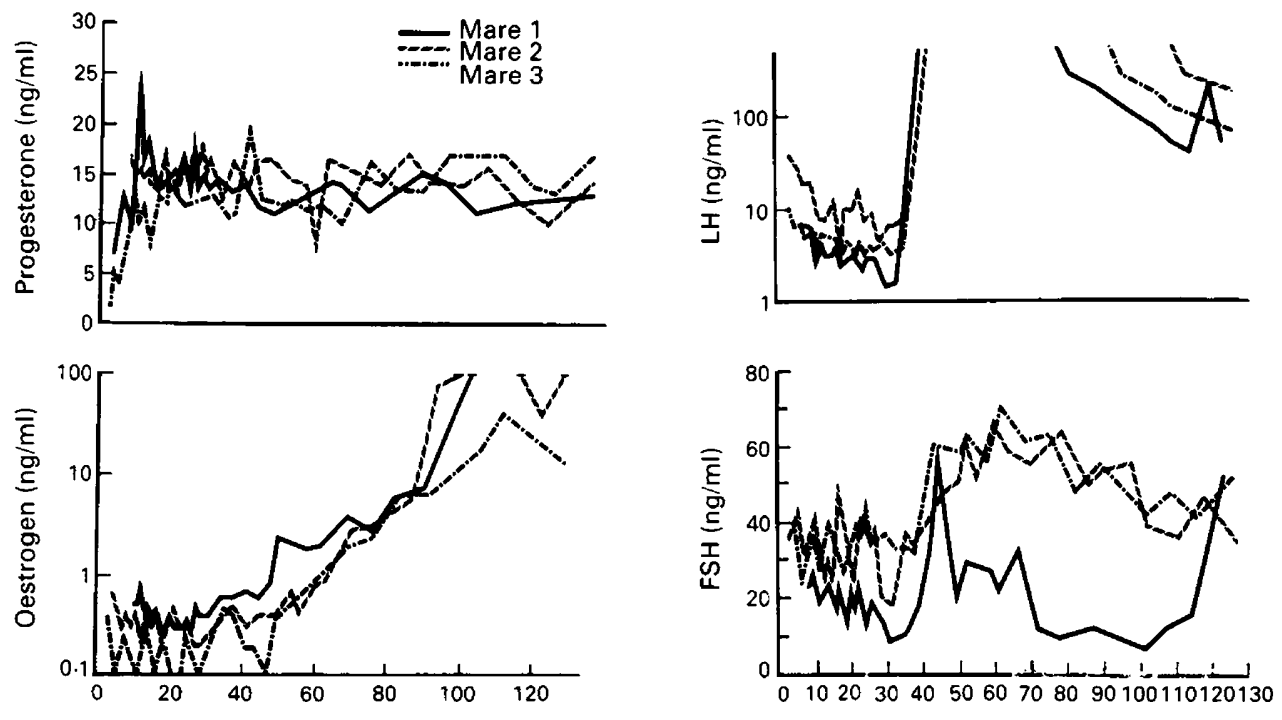

Days

Fig. 2. Hormone concentrations in the 3 pregnant ovariectomized recipient mares. Progesterone administration was discontinued on Day 100. 


\section{Hormone measurements}

The difference between pregnant and non-pregnant ovariectomized mares was not significant $(P>0.05)$ for any of the assayed hormones (Fig. 1). There was an effect of day for LH concentrations $(P<0.05)$ for both groups, as LH concentrations decreased over time.

Progesterone, total plasma oestrogens, FSH and LH values to Day 130 for the 3 pregnant ovariectomized recipients are shown in Fig. 2.

\section{Discussion}

The ovarian hormone requirements for preparation of the uterus for pregnancy vary greatly between species. In most species studied, females ovariectomized in early pregnancy can maintain pregnancy if given only progesterone. Other species, including the mouse, rat, gerbil and lemming, require addition of oestrogen to allow embryo implantation (reviews, Sauer, 1979; Levasseur, 1984). In some carnivorous species such as the ferret, pregnancy has not been maintained with exogenous progesterone and oestrogen combinations after ovariectomy (Foresman \& Mead, 1978).

In contrast, the long-term ovariectomized female may have very different steroid requirements for establishment and maintenance of pregnancy. In these females the uterus has not been influenced by steroid hormones immediately before pregnancy. Well studied in this regard is the long-term ovariectomized ewe. To maintain pregnancy after embryo transfer, the ewe requires progesterone, preceded by priming oestrogen, preceded by a separate, initial dose of progesterone (Miller \& Moore, 1976). The rat and mouse also require oestrogen administration before progesterone to maintain pregnancy after transfer in long-term ovariectomized females (Psychoyos, 1961; Humphrey, 1969).

Requirements for pregnancy in long-term ovariectomized females have not been well established in other species. Progesterone alone does not appear to maintain pregnancy after embryo transfer in long-term ovariectomized rabbits (Arthur \& Daniel, 1972), but may in the hamster (Orsini \& Psychoyos, 1965). Pregnancy has been maintained after embryo transfer by using oestrogen and progesterone treatment in long-term ovariectomized cows (Inskeep, 1984) and macaques (Hodgen, 1983), and in women with no apparent ovarian activity (Lutjen et al., 1984; Feichtinger \& Kemeter, 1985). No attempt was made in these instances to establish pregnancy using only progesterone.

In the present study, 3 of 4 long-term ovariectomized mares given progesterone maintained pregnancy after 7 embryo transfers, and continued the pregnancy to term. Mares were untreated for 10-27 days before beginning treatment associated with pregnancy. No oestrogen was given to these mares, and oestrogen concentrations remained low before and for $\mathbf{4 0}$ days after transfer. It is apparent from this study that oestrus itself is not necessary for subsequent establishment of pregnancy in the mare.

After transfer, embryonic oestrogen may contribute to the uterine environment of the ovariectomized recipients. The function of the oestrogen produced by the horse embryo may be to stimulate uterine tone or the production of glandular secretions, or to help signal maternal recognition of pregnancy, as in the sow (Bazer \& Thatcher, 1977). In this study no increase in peripheral plasma oestrogens was seen in early pregnancy, suggesting that the oestrogen produced by the embryo may act largely at a local level.

No differences in plasma LH or FSH were shown between the pregnant and nonpregnant ovariectomized recipients to Day 20. This agrees with findings for intact mares (Urwin \& Allen, 1982), and is further indication that recognition of pregnancy in the mare does not involve major changes in these hormones.

Progesterone concentrations in the ovariectomized mares were similar to those given for an intact pregnant (control) recipient. Progesterone was maintained at a fairly constant level throughout the time of administration in the pregnant mares. A small drop in progesterone was seen in 
Mares 2 and 3 after cessation of treatment at Day 100, but values remained well above the 'critical' level of $4 \mathrm{ng} / \mathrm{ml}$ (Shideler et al., 1982) due to progesterone production by the placenta. The rise in oestrogen in the pregnant mares at around Day 50 is attributed to the synthesis of oestrogen and related compounds by the fetal-placental unit. This rise in oestrogen is similar to that reported for mares ovariectomized in early pregnancy and maintained on progesterone (Terqui \& Palmer, 1979). FSH concentrations in the non-pregnant or pregnant ovariectomized mares were higher than in the intact mare, and showed no change over time, which may reflect lack of ovarian inhibin influence. The significant decrease in $\mathrm{LH}$ concentrations in the first 10 days in pregnant and nonpregnant ovariectomized recipients is probably due to suppression of pituitary $\mathrm{LH}$ output by administration of progesterone. In the pregnant mares a sharp rise in $\mathrm{LH}$, reflecting production of horse CG, started as early as Day 36 (Mare 1) and all mares had levels over $100 \mathrm{ng} / \mathrm{ml}$ by Day 40. This agrees with reported patterns of horse CG measured in intact mares (Urwin \& Allen, 1982; Kindahl et al., 1982).

In conclusion, ovariectomized mares treated with progesterone can establish and maintain pregnancy after transfer of a 7-day embryo. The resulting pregnancy appears to be physiologically normal, and continues uneventfully to term.

We thank Thornbook Farm and Wonderland Farms for their support of this project, Dr M. C. Garcia for help in statistical analysis, and M. Thierry Bridonneau, Ms LaRue Manning and Ms Margaret Cummings for excellent technical assistance.

\section{References}

Arthur, A.T. \& Daniel, J.C (1972) Progesterone regulation of blastokinin production and maintenance of rabbit blastocysts transferred into uteri of castrate recipients. Fert. Steril. 23, 115-122.

Bazer, F.W. \& Thatcher, W.W. (1977) Theory of maternal recognition of pregnancy in swine based on estrogen controlled endocrine versus exocrine secretion of prostaglandin $F 2 \alpha$ by the uterine endometrium. Prostaglandins 14, 397-401.

Blanc, M.R. \& Poirer, J.C. (1979) An homologous radioimmunoassay for ovine follitropin: development and characterization. Annls Biol. anim. Biochem. Biophys. 19, 1011-1026.

Combarnous, Y. \& Henge, M.H. (1981) Equine folliclestimulating hormone: purification, acid dissociation, and binding to equine testicular tissue. J. biol. Chem. 256, 9567-9572.

Davies, C.J., Antczak, D.F. \& Allen, W.R. (1985) Reproduction in mules: Embryo transfer using sterile recipients. Equine vet. J., Suppl. 3, 63-67.

Douglas, R.H. (1982) Some aspects of equine embryo transfer. J. Reprod. Fert., Suppl. 32, 405 408.

Feichtinger, W. \& Kemeter, P. (1985) Pregnancy after total ovariectomy achieved by ovum donation. Lancet i, 722-723.

Flood, P.F., Betteridge, K.J. \& Irvine, D.S. (1979) Oestrogens and androgens in blastocoelic fluid and cultures of cells from equine conceptuses of 10-22 days gestation. J. Reprod. Fert., Suppl. 27, 413-420.

Foresman, K.R. \& Mead, R.A. (1978) Luteal control of nidation in the ferret. Biol. Reprod. 18, 490-496.

Ginther, O.J. (1983) Mobility of the early equine conceptus. Theriogenology 19, 603-611.

Ginther, O.J. (1986) Ultrasonic Imaging and Repro- ductive Events in the Mare, pp. 142-149. Equiservices, Cross Plains, Wisconsin.

Ginther, O.J., Garcia, M.C., Bergfelt, D.R., Leith, G.S. \& Scraba, S.T. (1985) Embryonic loss in mares: pregnancy rate, length of interovulatory intervals, and progesterone concentrations associated with loss during days 11 to 15 . Theriogenology 24, 409-417.

Heap, R.B., Hamon, M. \& Allen, W.R. (1982) Study on oestrogen synthesis by the pre-implantation equine conceptus. J. Reprod. Fert., Suppl. 32, 343-352.

Hershman, L. \& Douglas, R.H. (1979) The critical period for the maternal recognition of pregnancy in pony mares. J. Reprod. Fert., Suppl. 27, 395-401.

Hodgen, G.D. (1983) Surrogate embryo transfer combined with estrogen-progesterone therapy in monkeys. J. Am. med. Assoc. 250, 2167-2171.

Holtan, D.W., Squires, E.L., Lapin, D.R. \& Ginther, O.J. (1979) Effect of ovariectomy on pregnancy in mares. J. Reprod. Fert., Suppl. 27, 457-463.

Humphrey, K.W. (1969) Induction of implantation of blastocysts transferred to ovariectomized mice. $J$. Endocr. 44, 299-305.

Inskeep, E.K. (1984) Successful transfer of bovine embryos into ovariectomized recipients. W. Virginia Agric. Exp. Stn, Ann. Rep. pp. 5-7.

Kenney, R.M. (1978) Cyclic and pathologic changes of the mare endometrium as detected by biopsy, with a note on early embryonic death. J. Am. vet. med. Assoc. 172, 241-262.

Kenney, R.M., Bergman, R.V., Cooper, W.L. \& Morse, G.W. (1975) Minimum contamination techniques for breeding mares: Technique and preliminary findings. Proc. 21st Meeting, Am. Ass. equine Pract. pp. 327-336. 
Kindahl, H., Knudsen, O., Madej, A. \& Edqvist, L.E. (1982) Progesterone, prostaglandin F-2a, PMSG, and oestrone sulphate during early pregnancy in the mare. J. Reprod. Fert., Suppl. 32, 353-359.

Levasseur, M.C. (1984) The involvement of estradiol at the time of implantation in placental mammals. Anim. Reprod. Sci. 7, 467-488.

Licht, P., Bona-Gallo, A., Aggarval, B.B., Farmer, S.W., Castelino, J.B. \& Papkoff, H. (1979) Biological and binding activities of equine pituitary gonadotrophins and pregnant mare gonadotrophin. J. Endocr. 83, $311-322$.

Loy, R.G., Pemstein, R., O'Canna, D. \& Douglas, R.H. (1981) Control of ovulation in cycling mares with ovarian steroids and prostaglandins. Theriogenology $15,191-200$.

Lutjen, P., Trounson, A., Leeton, J., Findlay, J., Wood, C. \& Renou, P. (1984) The establishment and maintenance of pregnancy using in vitro fertilization and embryo donation in a patient with primary ovarian failure. Nature, Lond. 307, 174-175.

McDowell, K.J., Sharp, D.C., Peck, L.S. \& Cheves, L.L. (1985) Effect of restricted conceptus mobility on maternal recognition of pregnancy in mares. Equine vet. J., Suppl. 3, 23-24.

Miller, B.G. \& Moore, N.W. (1976) Effects of progesterone and oestradiol on RNA and protein metabolism in the genital tract and on survival of embryos in the ovariectomized ewe. Aust. J. biol. Sci. 29, 565-573.

Orsini, M.W. \& Psychoyos, A. (1965) Implantation of blastocysts transferred into progesterone treated virgin hamsters previously ovariectomized. $J$. Reprod. Fert. 10, 300-301.

Palmer, E. \& Terqui, M. (1977) The measurement of total plasma oestrogens during the follicular phase of the mare's oestrous cycle. Theriogenology 7, 331-338.

Parry, L.C. \& Holtan, D.W. (1985) Effect of regumate, a synthetic progestin, on early pregnancy maintenance in the absence of functional corpora lutea in pony mares. Proc. 9th equine Nutr. Physiol. Symp. pp. 382-385.
Pelletier, J., Garnier, D.H., de Reviers, M.M., Terqui, M. \& Ortavant, R. (1982) Seasonal variation in LH and testosterone release in rams of two breeds. $J$. Reprod. Fert. 64, 341-346.

Psychoyos, A. (1961) Nouvelles recherches sur l'ovo' implantation. C. r. hebd. Séanc. Acad. Sci., Paris D 252, 2306-2307.

Sauer, M.J. (1979) Hormone involvement in the establishment of pregnancy. J. Reprod. Fert. 56, 725-743.

Sharp, D.C., Zavy, M.T., Vernon, M.W., Bazer, F.W., Thatcher, W.W. \& Berglund, L.A. (1984) The role of prostaglandins in the maternal recognition of pregnancy in mares. Anim. Reprod. Sci. 7, 269-282.

Shideler, R.K., Squires, E.L., Voss, J.L., Eikenberry, D.J. \& Pickett, B.W. (1982) Progestagen therapy of ovariectomized pregnant mares. J. Reprod. Fert., Suppl. 32, $459-464$.

Squires, E.L., Imel, K.J., Iuliano, M.F. \& Shideler, R.K. (1982) Factors affecting reproductive efficiency in an equine embryo transfer programme. J. Reprod. Fert., Suppl. 32, 409-414.

Terqui, M. \& Palmer, E. (1979) Oestrogen patterns during early pregnancy in the mare. J. Reprod. Fert., Suppl. 27, 441-446.

Urwin, V.E. \& Allen, W.R. (1982) Pituitary and chorionic gonadotrophic control of ovarian function during early pregnancy in equids. $J$. Reprod. Fert., Suppl. 32, 371-381.

Zavy, M.T., Mayer, R., Vermon, M.W. \& Sharp, D.C. (1979) An investigation of the uterine luminal environment in non-pregnant and pregnant pony mares. J. Reprod. Fert., Suppl. 27, 403-411. 